\title{
FRONT-END PLANNING - THE ROLE OF PROJECT GOVERNANCE AND ITS IMPACT ON SCOPE CHANGE MANAGEMENT
}

\author{
Eric Too ${ }^{1 *}$, Tiendung Le ${ }^{1}$, Wei Yee Yap ${ }^{1}$ \\ ${ }^{1}$ RMIT University, 124 La Trobe Street, Melbourne VIC 3000, Australia
}

(Received: February 2017 / Revised: March 2017 / Accepted: October 2017)

\begin{abstract}
To achieve optimal value from investment in a project there must be a clear link between the outputs created by the project and the goals of the organization. As such, organizations must have a structure in place for aligning the project deliverables with their organizational goals. Project governance is therefore critical in influencing the success or failure of projects. Lack of support, conflicting objectives, and other contextual issues in the domain of senior management can have negative influences on the progress and outcomes of a project. This paper examines the role of project governance in the new low cost carrier hub known as Kuala Lumpur International Airport 2 (KLIA2). It analyzes the KLIA2 case based on information available in the public domain. Specifically, it examines how governance was exercised in the project and how it impacted on the project's scope and outcome. The analysis of the case provides lessons that can be learned to improve governance practice and project success rates. The findings can also serve as a guide to organizations for designing effective governance structures that can enable projects to deliver benefits to the organization and its stakeholders.
\end{abstract}

Keywords: Project governance; Project scope; Project success; Scope management

\section{INTRODUCTION}

Infrastructure projects are often unique, arising from their distinctive social, political and environmental requirements. Consequently, they are shrouded in complexities and uncertainties. In addition, the management of infrastructure projects is challenging due to complex interfaces (Osipova \& Eriksson, 2013), lack of prior experience (Tang et al., 2006) and the involvement of a variety of stakeholders (Olander \& Landin, 2005). To this end, pre-project planning plays an important role in ensuring the success of infrastructure projects (Berawi, 2017). Research has shown that greater pre-project planning efforts lead to improved performance in the areas of cost, schedule and operational characteristics (Griffith et al., 1999).

One of the major sub-processes of the pre-project planning process is the development of the project scope. It is at this crucial stage that risks associated with the project are analyzed and the specific project execution approach is defined (Cho \& Gibson, 2001). Consequently, to achieve successful outcomes for infrastructure projects, a well-defined set of project scopes must be determined, along with input from all key stakeholders, before project deliverables are carried out (Turner, 2009). There is a saying that 'projects don't fail at the end, they fail at the beginning' (Rosenau \& Githens, 2005). If a project has received thorough scope planning at the initial stage, it offers anticipated project success and considerable opportunities to the firm in term of social and economic value.

*Corresponding author's email: eric.too@rmit.edu.au, Tel: +61 3 99250192, Fax: +61 399251939 Permalink/DOI: https://doi.org/10.14716/ijtech.v8i6.708 
Research has shown a strong link between project governance and project success (Beleiu \& Nistor, 2015; Joslin \& Müller, 2016). Scope management is crucial for project success as it determines and clarifies the deliverables of the scope before the project phase moves on and integrates with other project management processes (Khan, 2006). However, there is a dearth of studies examining the impact of project governance on the project scope management process, and the differing outcomes that result. This paper seeks to bridge this gap by investigating key elements within the project governance structure that influence the outcomes of scope management. To achieve this goal, the main research question formulated is:

- What are the key elements within the project governance structure that influence the outcomes of scope management?

The paper begins by reviewing key elements of scope management and this is followed by an overview of governance theory in project management. It then analyzes and presents the KLIA2 case, based on information available in the public domain relating to how its governance structure influenced the management of scope. A discussion of the key elements of governance structure that can enable projects to deliver benefits to the organization and its stakeholders is then provided. The paper ends by providing concluding remarks on the key lessons drawn that can serve as a guide to organizations in designing effective governance structures.

\section{LITERATURE REVIEW}

\subsection{Project Scope Management}

Scope management refers to "the processes required to ensure that the project includes all the work required, and only the work required, to complete the project successfully" (PMI, 2013). The main purpose of project scoping is to clearly define the project boundaries of what is included in the project deliverables required, and what is explicitly excluded. Thus, it forms the preliminary baseline for the establishment of the project timeline, budget and resources, and risk analysis, as well as project quality measurement (Dumont et al., 1997; Khan, 2006). The planning of project scope is an iterative process, with many revisions being created over time (Khan, 2006). It is crucial to determine and clarify the deliverables of the scope before the project phase moves on, because it integrates with other knowledge area processes (PMI, 2013); this also means that whenever there is a change in the project scope planning, it will reflect on the other knowledge area processes as well.

Once the scope parameters have been established and agreed by all the key stakeholders, the project manager will then use them to develop a scope management plan. This plan documents the validation of the project scope and describes a definition of each aspect of the scope and how it will be controlled. The project scope management plan is measured alongside the project requirements and the project management plan, to identify deficiencies in performance which may occur in the execution of the work. This allows the project manager to implement suitable strategies to improve work progress and to provide decision support for successful delivery of the project (PMI, 2013).

A well-conceived scope management plan determines and clarifies the deliverables of the project and provides a focused direction to allow the project manager to work towards the predefined goal and objectives. It promotes an explicit understanding among project teams and related stakeholders of project deliverables at the varying stages of the project. This conveys a sense of achievable project performance for the project goals. As a result, the scope management plan helps in reducing confusion and resolving conflicts during the project life cycle, particularly as a result of the predefined, validated scope management plan. Additionally, it strengthens the commitment and collaboration of the project teams, and is likely to boost team productivity as well as the project's success rate. The scope management plan also helps 
the project manager to avoid contravening stakeholders' expectations by exceeding project budget or overrunning project timelines.

It is commonly believed that the flexibility of the decision maker and the cost of making amendments are opposites. Decision makers can juggle with different ideas and strategic solutions to a problem in the initial stages, but once decisions are being made, essential choices become fixed, and it is more difficult and expensive to change the overall design (Samset \& Volden, 2016). Therefore, it is important to plan ahead at the initial stage, when many ideas and solutions are still flexible.

\subsection{Project Governance}

The concept of project governance has grown exponentially in popularity since 2005 (Biesenthal \& Wilden 2014), as researchers have widened the scope of possible success factors that focus on the structural characteristics of the project context (Joslin \& Müller, 2016). Project governance is an essential component of corporate governance and coexists within the corporate governance framework, with the objective of supporting projects in achieving their organizational objectives (Müller, 2009; Too \& Weaver, 2014). The concept of corporate governance relates to how a corporation is directed (by processes, policies, laws, and institutions) and to how different stakeholders (directors, managers, shareholders, staff, suppliers, and customers) work with each other to achieve corporate goals (Sharma et al., 2009). The focus of project governance is at the individual project level. It is important that the individual project is aligned to organizational objectives and delivered efficiently and sustainably. In this regard, project governance creates the structure needed for setting and achieving project objectives, and monitoring performance (Turner, 2009). In other words, it is "the use of systems, structures of authority, and processes to allocate resources and coordinate or control activity in a project" (Pinto, 2014).

As project governance is aligned with corporate governance, and good governance is associated with management performance, research has shown that there is a strong link between project governance and project success (Beleiu \& Nistor, 2015; Joslin \& Müller, 2016). Good project governance is therefore essential for success to be achieved and for sustainable value to be created for the organization and all the stakeholders involved (Too \& Weaver, 2014). In this context, good project governance provides a system of appropriate checks and balances that enable transparency, accountability and defined roles (Müller, 2009), while at the same time delivering the project effectively and efficiently in support of organizational objectives.

The key role of a project governance system is providing oversight and assurance (Too \& Weaver, 2014). Such a system includes: (a) aligning project goals with the current strategic plan in conjunction with executive management; (b) modifying the strategic plan in response to changing circumstances; (c) monitoring performance of projects within the strategic plan and the stewardship (effective allocation) of resources applied to these projects; and (d) communicating these assurances as appropriate to external stakeholders, the organization's owners, and the wider stakeholder community (including regulatory authorities).

\subsection{Project Governance and its Effect on Project Scope Management}

A successful project is one that delivers its outputs and significantly achieves agreed objectives. However, there are many challenges that must be overcome in achieving project success, such as underestimation of costs and overestimation of benefits, unrealistic and inconsistent assumptions, and the availability of essential planning data. Its objectives should be consistent with the needs and priorities of its stakeholders and it should be viable in the sense that the intended long term benefits resulting from the project are achieved (Samset \& Volden, 2016). Recent literature has highlighted the front-end phase, including project definition and scope management, as important for ensuring strategic project success (Merrow, 2011; Morris, 2013). 
When a project fails strategically, it is likely that the cause can be traced back to decisions in the earliest phases, when the initial idea was conceived and developed (Samset \& Volden, 2016). A well-conceived scope management plan determines and clarifies the deliverables of the project and provides a focused direction for the project manager to use in working towards predefined goal and objectives. It also helps in tracking the causality events that occur throughout the entire project life cycle. Thus, the project manager is able to foresee the project outcomes and avoid exceeding project budget and the overrun of project timeline.

A key task in the early phase of the project is to identify possible ways to solve the problem it has been mandated to solve. Additionally, the importance of scope planning and its management must be recognized and properly governed. The priority at this stage is to establish an overall perspective and to analyze the problem in its context and considering the needs and priorities of stakeholders, users and affected parties, in order to come up with a sensible strategy (Samset \& Volden, 2016).

As in any well-managed project, to ensure that scope management is properly governed three key areas need to be considered. First, it is important to ensure that the appropriate project organization structure is in place and formally documented (Marnewick \& Labuschagne, 2011). All projects should have people identified and held responsible for: (a) governing the project to ensure that managerial and technical oversight is maintained; (b) sponsoring the project in pursuit of stated organizational needs or objectives; and (c) managing the project on a day-today basis, ensuring that the deliverables are appropriate to the delivery of the desired outcomes (Too \& Weaver, 2014). The second consideration is for the levels of authority and constituency of any decision-making body to be defined within the governance arrangements (Garland, 2009; Müller, 2009; Too \& Weaver, 2014). For projects, governance is typically required for authorizing the start of projects and each phase of a project, authorizing changes to the project, and ensuring compliance with the organization's policies and any applicable legal or regulatory requirements. The third consideration refers to regulation of the quality of any outputs, including the application of any organizational constraints, such as standards and components to be used and support by an appropriate assurance system (Müller, 2009; Too \& Weaver, 2014).

\section{The Case - KLIA 2}

In 2007, Malaysia Airports Holdings Bhd (MAHB), the owner and operator of both Kuala Lumpur International Airport (KLIA) and Low Cost Carrier Terminal (LCCT), proposed the development of a new low cost carrier (LCC) hub known as Kuala Lumpur International Airport 2 (KLIA2), to replace the overstretched and congested LCCT following the business expansion of AirAsia (the main tenant of the airport). The project was privately funded by the airport operator, MAHB, as part of the government's economic stimulus package to promote the nation's economic growth and employment opportunities. KLIA2 is located 1.5 kilometers from the west side of the main terminal, KLIA. The site was selected based on the recommendation provided in the National Airport Master Plan, 2008 (NAMP), and a wide-ranging study involving a selection of stakeholders including the Ministry of Transport, the Ministry of Finance, the Ministry of Home Affairs, the Department of Civil Aviation (DCA), and the airlines.

It was designed to cater for a capacity of 30 million passengers a year, including both domestic and international LCC flights. The preparation of the project began in October 2009, at which stage all stakeholders were involved in intensive meetings for the discussion of the project 
scope and requirements. The construction of the new terminal commenced in the third quarter of 2010 and it was projected to be delivered in April 2012, based on a 20-month construction period, and at a cost of RM 2 billion ( $\$ 780$ million). The new terminal consisted of a 2-storey terminal building with a gross floor area of 150,000 square meters and two blocks of 8 -storey car parks which would provide 6,000 parking spaces for both the travelers and staff. On the airside, the construction compromised 50 semi-contact aircraft stands, a 2.5 kilometer parallel runway for quick turnaround, a 77 meter air control tower and an 8 kilometer public infrastructure. These works comprised a total of 37 work packages.

\subsection{The Design and Bidding Process}

In 2009, MAHB appointed KLIA Consultancy Services (KLICS) as the project management consultant to oversee the design, construction, consultancy, and tendering processes of KLIA2, in view of their previous experience as the project manager of the successfully completed KLIA. To achieve the targeted delivery date of the project, MAHB decided to use the open tender method, in which all qualified bidders were invited to bid for the various work packages. These included contracts for site preparation, earthworks, main drainage, supporting infrastructures, control tower, and construction of the gateway, runway and taxiways, with a total number of 42 contractors being awarded jobs from the project. However, the major package, worth RM 1 billion ( $\$ 390$ million) for the main terminal and satellite building was reserved for highly reputable and eligible contractors, due to the urgency for completion within the set project duration of 20 months, from Aug 2010 to April 2012.

The main terminal and satellite building contract of RM 1 billion was awarded as a single design-and-build contract package in 2010 to a joint venture between two major industry players, UEM Construction Sdn Bhd and Bina Puri Sdn Bhd (UEMCBinapuri JV). KLIA2 was designed by a joint collaboration of local architecture firms, LKMD Architecture Sdn. Bhd, A.Hanapiah Architect, and Arkitek ICB Sdn. Bhd, under consultation with KLICS and Netherland Airport Consultants B.V. (NACO).

\subsection{The Construction}

Adhering strictly to the targeted deadline, the design drawing of the terminal had to be completed, submitted and approved within six months of the date of commencement (August 2010). After acquiring approval, the design was intended to be fixed. Given the need to shorten the time required in reaching the deadline, a fast-track project delivery strategy, in which construction started before the design was completed, was employed.

During the design process, a concept design consultants (CDC) team was set up by MAHB to review and audit the engineering and architectural drawings submitted by the contractor's design consultant team (the architects) to ensure compliance with the contract requirements and regulatory standards. However, the CDC team decided to take the lead in redesigning the LCC into a high-cost terminal (which was outside their job scope) and as a result made a series of changes. The contractors were tasked to resubmit the drawings for approval while the original tender submission had already gone through several "value engineering" iterations involving resizing, downsizing and modifying. As a result, the project encountered its first delay and completion was pushed back to October 2012, with the total cost increasing to RM 2.5 billion (\$972 million).

Throughout the fall of 2010, the construction of KLIA2 continued at a rapid pace. By late March 2011, more than 40 percent of the work packages had been completed and the project seemed to be progressing well in terms of maintaining its schedule. However, starting in the third quarter of 2011, the relationship between MAHB and AirAsia began to sour. A series of substantial changes were created as AirAsia underwent a business model transformation. Among the changes were the upgrading of the semi-automated baggage handling system to a 
fully automated system, which involved hacking into structures that were already installed, lengthening the original runway from 2.5 kilometers to 4 kilometers and expanding its width to 2.2 kilometers to cater for Airbus A380, a further separation of 2.2 kilometers runway, a provision of a bigger terminal space to cater for a capacity of 45 million passengers per annum, and an upgrade from 50 semi-contact aircraft stands to 68 fully automated contact stands and an additional eight remote stands.

Public disputes between MAHB and AirAsia became increasingly tense as the project schedule again slipped. Indecisiveness by both parties about aerobridge installation also resulted in a lengthy public disagreement lasting for more than five months. MAHB had been planning to install 80 aerobridge stand facilities, while AirAsia initially refused to use these, but was compelled to accept them later, based on poll surveys of public requests.

More scope changes were necessary when the Home Ministry demanded that the government's security measures regarding immigration controls should include a complete separation between the international arrivals and departure halls, as well as a segregation of the halls between domestic and international passengers. To accommodate these requests, the design was altered from the original 2-storey $(150,000$ square meters) terminal building to a revised 9storey building of almost twice its original size, at 255,000 square meters. Table 1 provides a summary of the changes in scope to the KLIA2 project.

Table 1 Summary of changes in scope

\begin{tabular}{|c|c|c|c|}
\hline Items & Provisional RM 2 bilion & Revised RM 4 billion & Increase in Scope \% \\
\hline 1. Terminal Building & $150,000 \mathrm{~m}^{2}$ & $257,000 \mathrm{~m}^{2}$ & $71.3 \%$ \\
\hline 2. Aircraft Stand & $\begin{array}{l}\text { Area: } 500,000 \mathrm{~m}^{2} \\
\text { a. } 50 \text { semicontact stands }\end{array}$ & $\begin{array}{l}\text { Area: } 803,709 \mathrm{~m}^{2} \\
\text { a. } 68 \text { fully automated } \\
\text { contact stands } \\
\text { b. } 8 \text { remote stands } \\
\text { c. } 80 \text { aerobridges }\end{array}$ & $60.7 \%$ \\
\hline 3. Earthwork & Area: $4.88 \mathrm{mil} \mathrm{m}^{2}$ & Area: $11.19 \mathrm{mil} \mathrm{m}^{2}$ & $130.7 \%$ \\
\hline $\begin{array}{l}\text { 4. Runways, Taxiway, } \\
\text { Pavement \& AGL } \\
\text { System }\end{array}$ & $\begin{array}{l}\text { Length: } 2.5 \mathrm{~km} \\
\text { Width: } 45 \mathrm{~m}\end{array}$ & $\begin{array}{l}\text { Length: } 4 \mathrm{~km} \\
\text { Width: } 60 \mathrm{~m}\end{array}$ & $64.7 \%$ (area) \\
\hline 5. DCA Facilities & $\begin{array}{l}\text { Apron Control Tower } \\
\text { Height: } 77 \mathrm{~m}\end{array}$ & $\begin{array}{l}\text { Air Traffic Control Tower } \\
\text { Height: } 90 \mathrm{~m}\end{array}$ & $\begin{array}{r}20.8 \% \text { (height) } \\
115.4 \% \text { (nav. Alds) }\end{array}$ \\
\hline 6. Public Infrastructure & $\begin{array}{l}\text { Length: } 8 \mathrm{~km} \\
\text { With } 1.5 \mathrm{~km} \text { elevated road }\end{array}$ & $\begin{array}{l}\text { Length: } 15 \mathrm{~km} \\
\text { With } 5.4 \mathrm{~km} \text { elevated road }\end{array}$ & $\begin{array}{r}87.5 \% \\
260 \% \\
\end{array}$ \\
\hline 7. Work Package & 37 & 51 & $37.8 \%$ \\
\hline
\end{tabular}

In early 2012, the project management consultation contract was not renewed after its term ended in August 2011, and MAHB took over responsibility as the project management team for the project. At this point, the project had been delayed by 200 days.

In March 2012, after piling work costing RM4 million (\$156 million) had already been completed on the site, the DCA made a major change request to reposition the air control tower. DCA believed that the changes in the design scheme were necessary so that the new control tower would not interfere with the existing KLIA air control tower, and to provide optimal vision of all runways. To accommodate this request, MAHB decided to redesign and upgrade the control tower, shadowing the original blueprint but converting the LCCT into a hybrid airport serving both LCCs and full-service carriers. Consequently, the target completion date was pushed back further and cost rose from RM2.5 billion ( $\$ 972$ million) to RM 4 billion ( $\$ 1.56$ billion). The completion date was revised to May 2013. 
During April 2013 (two months before the planned opening of KLIA2 on 28 June 2013), the Department of Immigration discovered that their requirement for a ten minute service turnover was not achievable based on the planned 35 counters, and requested further changes to increase the immigration counters to 45 , plus additional ticket booths and counters.

In view of these changes, the main contractor, UEMCBinapuri JV, could not achieve the completion deadline and appealed for an extension. This was rejected by MAHB and both parties were embroiled in a public dispute which resulted in a fine of RM 60 million (\$23 million) being imposed on the contractor. MAHB announced a new completion date of February 2014. However, in February 2014, KLIA2 again slipped on its fifth delivery date. The situation worsened when AirAsia reversed their decision regarding the fully automatic baggage handling system that it had previously agreed a year and a half earlier. KLIA2 was finally opened on 2 May 2014, at a cost of RM4 billion instead of the initial RM1.7 billion.

\section{DISCUSSION}

\subsection{Lack of Project Governance Structure}

Project governance should be established to enable efficient and effective project decision making. A project governance structure is necessary so that appropriate persons are identified and held responsible for governing the project, to ensure that the project deliverables are appropriate in pursuit of stated organizational objectives (Too \& Weaver, 2014). In KLIA2, there was no appropriate governance structure established to address the needs of the project and to oversee the performance of the project activities. Instead, the project was managed based on the normal organization structure, as shown in Figure 1.

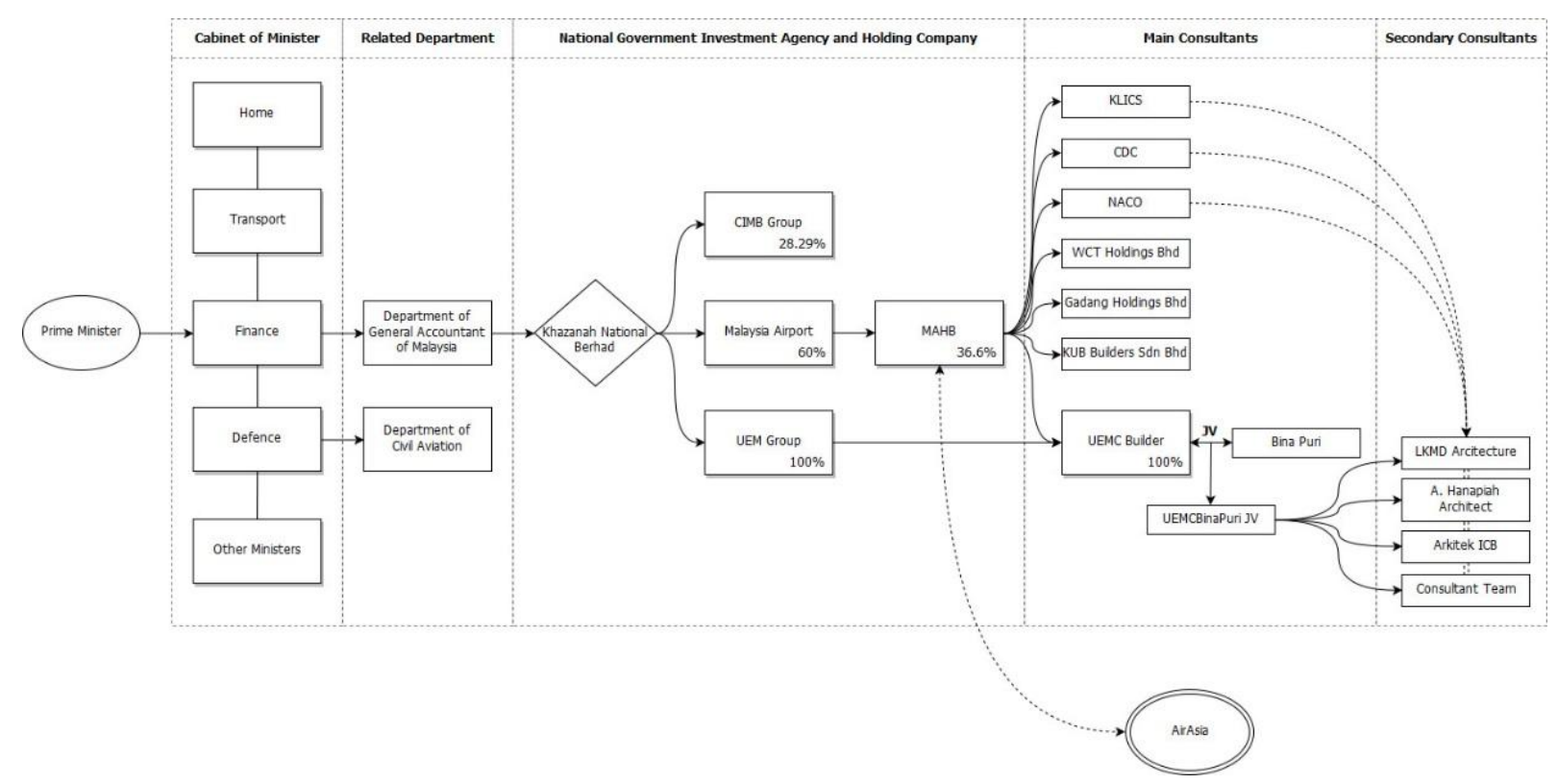

Figure 1 Organizational structure of the KLIA2 project

This blurring of integration of project structures and organization structures resulted in an organizational hierarchy that included persons in the decision-making process who may not have been best placed to make project decisions. Although KLICS was appointed as the project management consultant to coordinate the project activities of different stakeholders throughout the project life cycle, CDC was appointed separately by MAHB to review and audit engineering and architectural drawings submitted by the contractor. Due to a lack of project governance structure, CDC had taken the lead, instead of KLICS, and had made a series of changes to the 
scope and redesigned KLIA2 as a high-cost terminal. In addition, the lack of a project governance structure resulted in the passive involvement of KLICS. With laissez-faire project management from KLICS, deliverables were being progressively added by the various key players throughout the project without considering the implications for overall project cost and time.

\subsection{Blurred Authority and Responsibilities}

Successful projects contribute to the broader strategic goals of the organization (Williams \& Samset, 2012). Here the primary role of project governance is to establish a shared set of rules and procedures that all firms participating in the project are expected to follow (Ahola et al., 2014). In the context of projects, these rules include the definition and regulation of roles, accountabilities, decision making, and boundary management (Mosavi, 2014). Project governance is typically required for authorizing the start of projects and each phase of a project, authorizing changes to the project, and ensuring compliance with the organization's policies and any applicable legal or regulatory requirements (Too \& Weaver, 2014). The lack of clear establishment of project governance structure blurs accountability within the decision-making process since it becomes largely impossible to distinguish the different accountabilities of the different layers within the structure (Garland, 2009). In the KLIA2 project, the lack of clarity of roles and responsibilities, as well as ownership of decision making within the project team and project setting, resulted in confusion. The contractor was tasked by the CDC team to resubmit drawings based on the new proposal by the CDC team without prior discussion with KLICS, and other stakeholders and authorities, of the scope changes. It would have been desirable for CDC to propose any changes in scope to KLICS as the project manager, so that appropriate consultation with MAHB and other key stakeholders could have been carried out before any decisions were made. The lack of clarity of authority and responsibilities also contributed to the inflated scope requirements in which there was no control over the scope changes throughout the execution of the project. Scope changes are not unusual as part of a project's life cycle; however, uncontrolled changes can often lead to project delays, as is evident in the case of KLIA2.

\subsection{Inadequate Assurance System}

Joslin and Müller (2016) suggest that project governance has an oversight function which collectively encompasses the project lifecycle to ensure a consistent approach to controlling the project, with the aim of ensuring its success. Monitoring and ensuring the accountability of project performance is, therefore, a common project governance function (Müller, 2009; Too \& Weaver, 2014; Turner, 2009). The case of KLIA2 can be seen as exemplifying immaturity in the practice of project management. KLICS failed to exercise the optimum level of project oversight, leading to the failure of progress monitoring which subsequently caused project delays. Additionally, there were no clear guidelines on the statement of need, employer's requirements and concept drawings. For this reason, the project scope was constantly changed in the later stage of the project. Moreover, the task of monitoring and controlling the project to achieve project goals was not allocated to the project manager, KLICS, which was the decisionmaking body tasked with reviewing the project on a regular basis. After the dismissal of the KLICS team, there was a lack of management continuity in the project. Although MAHB took over responsibility as the project manager, inputs from stakeholders were too numerous. User needs and expectations from the tenant, AirAsia, and regulatory requirements such as those relating to immigration, were not properly managed, resulting in the growing scope of the project. 


\section{CONCLUSION}

There are many reasons why projects fail. Some may be due to complicated technical issues, while others relate to unaddressed issues that ultimately lead to bigger and more complex problems. Sometimes there is a single trigger event that leads to failure, but often it is a tightly entwined set of problems that cumulatively results in failure. This paper examines the KLIA2 project that was completed after much delay and cost overrun. Despite the initial firm commitment to, and high expectations of, the project delivery, the project requirements were changed after much of the basic project planning had been performed. One of the key reasons for these problems can be attributed to the absence of good project governance. There was no appropriate governance structure to address the needs of the project. Without a clear project governance structure, there was no clarity of roles and responsibilities in the governance of the project, resulting in the poor management of scope changes throughout its execution. It is also noted that there was no clear assurance system to provide an oversight of the inflated scope requirements. In summary, the results of this study highlight the importance of an effective project governance framework with clear responsibilities for decision making, in order to provide assurance of the success of project scope management.

\section{REFERENCES}

Ahola, T, Ruuska, I, Artto, K, Kujala, J., 2014. What is Project Governance and what are its Origins?. International Journal of Project Management, Volume 32(8), pp. 1321-1332

Beleiu, I., Nistor, R., 2015. Project Governance and its Contribution to Projects Success. Managerial Challenges of the Contemporary Society, Volume 8(1), pp. 82-86

Berawi, M.A., 2017. Fostering Partnerships and Strategic Alliances in Sustainable Infrastructure Development. International Journal of Technology, Volume 8(4), pp. 568571

Biesenthal, C., Wilden, R., 2014. Multi-level Project Governance: Trends and Opportunities. International Journal of Project Management, Volume 32(8), pp. 1291-1308

Cho, C-S., Gibson, G.E., 2001. Building Project Scope Definition using Project Definition Rating Index. Journal of Architectural Engineering, Volume 7(4), pp. 115-125

Dumont, P.R., Gibson, G.E., Fish, J.R., 1997. Scope Management using Project Definition Rating Index. Journal of Management in Engineering, Volume 13(5), pp. 54-60

Garland, R., 2009. Project governance: a Practical Guide to Efficient Project Decision Making. London: Kogan Page

Griffith, A.F., Gibson, G.E., Hamilton, M.R., Tortora, A.L., Wilson, C.T., 1999. Project Success Index for Capital Facility Construction Projects. Journal of Performance of Constructed Facilities, Volume 13(1), pp. 39-45

Joslin, R., Müller, R., 2016. The Relationship between Project Governance and Project Success. International Journal of Project Management, Volume 34(4), pp. 613-626

Khan, A., 2006. Project Scope Management. Cost Engineering, Volume 48(6), pp. 12-16

Marnewick, C., Labuschagne, L., 2011. An Investigation into the Governance of Information Technology Projects in South Africa. International Journal of Project Management, Volume 29(6), pp. 661-670

Merrow, E.W., 2011. Industrial Megaprojects: Concepts, Strategies, and Practices for Success. New Jersey: John Wiley \& Sons

Morris, P., 2013. Reconstructing Project Management Reprised: A Knowledge Perspective. Project Management Journal, Volume 44(5), pp. 6-23

Mosavi, A., 2014. Exploring the Roles of Portfolio Steering Committees in Project Portfolio Governance. International Journal of Project Management, Volume 32(3), pp. 388-399

Müller, R., 2009. Project Governance. London: Gower 
Olander, S., Landin, A., 2005. Evaluation of Stakeholder Influence in the Implementation of Construction Projects. International Journal of Project Management, Volume 23(4), pp. 321-328

Osipova, E., Eriksson, P.E., 2013. Balancing Control and Flexibility in Joint Risk Management: Lessons Learned from Two Construction Projects. International Journal of Project Management, Volume 31(3), pp. 391-399

Pinto, J.K., 2014. Project Management, Governance, and the Normalization of Deviance. International Journal of Project Management, Volume 32(3), pp. 376-387

PMI, 2013. A Guide to the Project Management Body of Knowledge. $5^{\text {th }}$ Edition. Newton Square, PA: Project Management Institute

Rosenau, M.D., Githens, G.D., 2005. Successful Project Management: A Step-by-Step Approach with Practical Examples. $4^{\text {th }}$ Edition. New Jersey: John Wiley \& Sons

Samset, K., Volden, G.H., 2016. Front-end Definition of Projects: Ten Paradoxes and some Reflections regarding Project Management and Project Governance. International Journal of Project Management, Volume 34(2), pp. 297-313

Sharma, D., Stone, M., Ekinci, Y., 2009. IT Governance and Project Management: A Qualitative Study. Journal of Database Marketing \& Customer Strategy Management, Volume 16(1), pp. 29-50

Tang, W., Duffield, C.F., Young, D.M., 2006. Partnering Mechanism in Construction: An Empirical Study on the Chinese Construction Industry. Journal of Construction Engineering and Management, Volume 132(3)

Too, E.G., Weaver, P., 2014. The Management of Project Management: A Conceptual Framework for Project Governance. International Journal of Project Management, Volume 32(8), pp. 1382-1394

Turner, J.R., 2009. The Handbook of Project-based Management. London: McGraw Hill

Williams, T.M., Samset, K., 2012. Project Governance: Getting Investments Right. Hampshire: Palgrave Macmillan 